\title{
Photosynthetic characteristics of phycoerythrin- containing marine Synechococcus spp. II. Time course responses of photosynthesis to photoinhibition
}

\author{
R. G. Barlow, R. S. Alberte \\ Department of Molecular Genetics and Cell Biology, Barnes Laboratory, The University of Chicago, 5630 S. Ingleside Avenue, \\ Chicago, Illinois 60637, USA
}

\begin{abstract}
Marine Synechococcus spp. optimize growth and photosynthesis at low light levels and show photoinhibition of photosynthesis at high levels. We examined the photosynthetic response to, and recovery from, exposure to photoinhibitory light levels after growth at low photon flux densities in 2 clones of Synechococcus spp. Clones WH 7803 and WH 8018 were grown at $25 \mu \mathrm{E} \mathrm{m} \mathrm{m}^{-2} \mathrm{~s}^{-1}$, exposed to photoinhibitory light $\left(1500 \mu \mathrm{E} \mathrm{m} \mathrm{m}^{-2} \mathrm{~s}^{-1}\right)$ for $3 \mathrm{~h}$, and then returned to the growth light level. Clone WH 7803 showed a $40 \%$ decrease in $\mathrm{P}_{\max }$ while Clone WH 8018 showed a $30 \%$ decrease during the exposure. This was accompanied by a proportional increase in whole-cell phycoerythrin fluorescence and by a decrease in the cellular content of P700, the photochemical reaction center of Photosystem I. On return to low light, photochemically active P700 recovered to pre-photoinhibitory levels within $1 \mathrm{~h}$ in Clone WH 8018 and within $2 \mathrm{~h}$ in Clone WH 7803. Photosynthetic rates and phycoerythrin fluorescence required 2 to $3 \mathrm{~h}$ and 3 to $4 \mathrm{~h}$ to recover in Clones WH 8018 and WH 7803, respectively. During exposure and recovery, no changes in cellular levels of chlorophyll or phycobiliproteins were observed. It is concluded that (1) the primary deleterious effect of photoinhibition of photosynthesis was reversible losses in Photosystem I activity, and (2) recovery from photoinhibition was rapid and occurred within hours.
\end{abstract}

\section{INTRODUCTION}

Synechococcus spp., containing phycoerythrin (PE), are an important fraction of the marine picoplankton (Johnson \& Sieburth 1979, Waterbury et al. 1979), and appear to contribute significantly to oceanic primary production (Glover et al. 1983, Li et al. 1983, Platt et al. 1983, Waterbury et al. 1983). Li et al. (1983) and Platt et al. (1983) have estimated that this cyanobacterial group can contribute as much as 60 to $80 \%$ of the total primary production in the tropical Pacific and tropical North Atlantic. These values may be overestimates as large numbers of green flagellates of the group Prasinophyta are commonly found among the picoplankton fraction (Glover \& Keller 1984, Yentsch 1984). It is clear, however, that Synechococcus spp. can account for at least 10 to $20 \%$ of the primary produc-

Addressee for reprint requests tion in the temperate North Atlantic and Sargasso Sea (Waterbury et al. 1983).

Investigations of the photosynthetic characteristics of Synechococcus spp. have revealed that they photosynthesize and grow optimally under low photon flux densities common in the lower euphotic zone (Morris \& Glover 1981, Alberte et al. 1984, Barlow \& Alberte 1985), and that at least one dominant clonal type (WH 7803; Alberte et al. 1984) shows significant photoinhibition in photosynthesis versus irradiance (P-I) relations (Barlow \& Alberte 1985). Photoinhibition is also expressed in division rates of Clones WH 7803 and WH 8018 grown under photon flux densities greater than $100 \mu \mathrm{E} \mathrm{m} \mathrm{m}^{-2} \mathrm{~s}^{-1}$; divisions $\mathrm{d}^{-1}$ are half that observed at $25 \mu \mathrm{E} \mathrm{m}^{-2} \mathrm{~s}^{-1}$ (Barlow \& Alberte 1985). Further, maximal photosynthesis $\left(\mathrm{P}_{\max }\right)$ per cell or per chlorophyll (chl) a for both clones is negatively correlated $\left(\mathrm{r}^{2}=0.95\right.$ to 0.99$)$ with growth photon flux density (Barlow \& Alberte 1985). Therefore, photoinhibitory effects on the growth and photosynthesis of 
Synechococcus spp. can extend beyond the short-term effects observed in P-I relations.

Many studies of P-I relations of marine phytoplankton have revealed a decline in $\mathrm{P}_{\max }$ at high photon flux densities (for review see Richardson et al. 1983). This photoinhibitory response, though widespread in lowlight adapted cells (e.g. Perry et al. 1981, Gallagher et al. 1984) or benthic species (Gerber \& Burris 1981. Falkowski 1984), is not well understood. Samuelsson \& Richardson (1982) suggested that Photosystem II was the site of photoinhibition while other studies demonstrated specific losses of P700 (Photosystem I) in response to photoinhibitory light conditions (Gerber \& Burris 1981, Falkowski 1984). A recent report (Barlow \& Alberte 1985) demonstrated that the number of Photosystem I units (P700) per cell decreased as $P_{\max }$ decreased $\left(r^{2}=0.74\right.$ to 0.87$)$ in 2 clones of Synechococcus spp. Since there were concomitant losses in Photosystem II activity, it was concluded that losses in P700 photochemical activity blocked non-cyclic electron flow resulting in reduced Photosystem II activity, and the primary site of photosynthetic photoinhibition was Photosystem I photochemistry (Barlow \& Alberte 1985).

The present investigation sought to delineate the temporal response of the loss of P700 under photoinhibitory light and to determine the kinetics of its recovery.

\section{MATERIALS AND METHODS}

Cell culture and growth conditions. Axenic cultures of Synechococcus spp. Clones WH 7803 (DC-2) and WH 8018 (L1604) were obtained from the Culture Collection of Marine Phytoplankton, Bigelow Laboratory for Ocean Sciences. The cultures were maintained in $\mathrm{f} / 2$ enriched seawater (Guillard \& Ryther 1962 ) at $18^{\circ} \mathrm{C}$ under continuous illumination $\left(40\right.$ to $50 \mu \mathrm{E} \mathrm{m} \mathrm{m}^{-2} \mathrm{~s}^{-1}$ photosynthetically active radiation, PAR). Photon flux densities for the experiments were measured with an integrating $4 \pi$ quantum sensor (Biospherical Instruments, Model QSL-100).

Inocula (200 $\mathrm{ml}$ of early log cultures) were aseptically added to 21 of $f / 2$ medium and placed in a temperaturecontrolled growth chamber at $18^{\circ} \mathrm{C}\left( \pm 0.1 \mathrm{C}^{\circ}\right)$ under $25 \mu \mathrm{E} \mathrm{m} \mathrm{m}^{-2} \mathrm{~s}^{-1}$ (PAR) illumination provided by mixed halogen incandescent lamps. Cultures were agitated by stirring and sterile aeration. After $48 \mathrm{~h}$, cells in log growth were removed for pigment and photosynthetic determinations. These cells constituted the pre-photoinhibitory condition. The remaining cells were exposed to a photoinhibitory light level of $1500 \mu \mathrm{E} \mathrm{m}^{-2} \mathrm{~s}^{-1}$ (PAR) for $3 \mathrm{~h}$ and samples were collected at the end of this period for pigment and photosynthetic measurements. The cultures were then returned to the $25 \mu \mathrm{E} \mathrm{m}^{-2} \mathrm{~s}^{-1}$ light regime and samples collected at hourly intervals for analysis. For all time points 3 replicate samples were collected. Cell counts were made with the use of a haemocytometer and epifluorescent illumination.

Pigment analysis. Cells were disrupted in a French pressure cell ( 2 passes at $\left.18000 \mathrm{psi}\left[=1.2 \times 10^{8} \mathrm{~Pa}\right]\right)$ and aliquots were made $90 \%(\mathrm{v} / \mathrm{v})$ acetone with neat acetone. Chlorophyll a concentration was determined spectrophotometrically using the extinction coefficient of Jeffrey \& Humphrey (1975). Additional aliquots were diluted with $150 \mathrm{mM}$ Tris- $\mathrm{HCl}$ containing $4 \mathrm{mM} \mathrm{MgCl}$ $(\mathrm{pH} 8.0)$ and the PE concentration measured at 545 and $555 \mathrm{~nm}$ using the extinction coefficients determined in Alberte et al. (1984) for Clones WH 7803 and WH 8018 respectively. The concentrations of phycocyanin (PC) and allophycocyanin (APC) were determined from the simultaneous equations of Kursar \& Alberte (1983). Since the ratio of PC to APC does not change in these clones (Barlow \& Alberte 1985) the concentration of these 2 phycobiliproteins were summed for presentation. All determinations were done in triplicate.

Photosynthesis and photosynthetic unit determinations. Net photosynthetic rates were determined in triplicate in cells suspended in fresh $\mathrm{f} / 2$ medium containing 2 to $4 \mathrm{mM}$ sodium bicarbonate in a Clark-type oxygen electrode (Rank Bros., Cambridge, England). Maximal photosynthesis for both clonal types occurred at 200 to $230 \mu \mathrm{E} \mathrm{m}^{-2} \mathrm{~s}^{-1}$ (PAR) as determined from preliminary P-I curves. This light intensity was used for all the experimental photosynthetic measurements. Steady-state photosynthetic rates were achieved within 3 to $4 \mathrm{~min}$ of light exposure.

Photosynthetic units (PSU) size and numbers of Photosystem I units (P700) per cell were determined in Triton $\mathrm{X}-100$ solubilized thylakoids as previously described (Alberte et al. 1984). Cellular P700 content was determined by light-dark difference spectrophotometry (Kursar \& Alberte 1983). The number of P700's per cell was determined from PSU size based on P700 and the Chl a content per cell (Alberte et al. 1984). Numbers of phycobiliprotein chromophores required for PSU size calculations were determined as previously (Kursar \& Alberte 1983, Barlow \& Alberte 1985).

In vivo fluorescence. Cells were normalized to a whole cell PE $A_{\max }$ of $0.1(545 \mathrm{~nm}$ for Clone WH 7803 and $568 \mathrm{~nm}$ for Clone WH 8018) in fresh $\mathrm{f} / 2$ medium prior to fluorescence measurements. The PE fluorescence emission (quanta corrected) was measured on a fully corrected Amino SPF-500 spectrofluorometer at $560 \mathrm{~nm}( \pm 1 \mathrm{~nm})$ for Clone WH 7803 and at $574 \mathrm{~nm}$ $( \pm 1 \mathrm{~nm})$ for Clone $\mathrm{WH} 8018$, with excitation at $525 \mathrm{~nm}$ $( \pm 10 \mathrm{~nm})$. Chlorophyll a fluorescence emission was measured at $680 \mathrm{~nm}$. Levels of PE fluorescence emission were expressed as the ratio of 560 or $574 \mathrm{~nm}$ emission to $680 \mathrm{~nm}$ emission of whole cells 


\section{RESULTS}

Maximum photosynthetic rates $\left(\mathrm{P}_{\max }\right)$ per cell of both clones decreased during the $3 \mathrm{~h}$ exposure to photoinhibitory light $\left(1500 \mu \mathrm{E} \mathrm{m} \mathrm{m}^{-2} \mathrm{~s}^{-1}\right)$ from about 32 to $22 \mu \mathrm{mol} \mathrm{O} \mathrm{C}_{2} \mathrm{cell}^{-1} \mathrm{~min}^{-1}\left(\times 10^{-12}\right)$ in Clone WH 8018, and from about 17.5 to $10.5 \mu \mathrm{mol} \mathrm{O}_{2}$ cell $^{-1} \mathrm{~min}^{-1}$ $\left(\times 10^{-12}\right)$ in Clone WH 7803 (Fig. 1). This corresponds

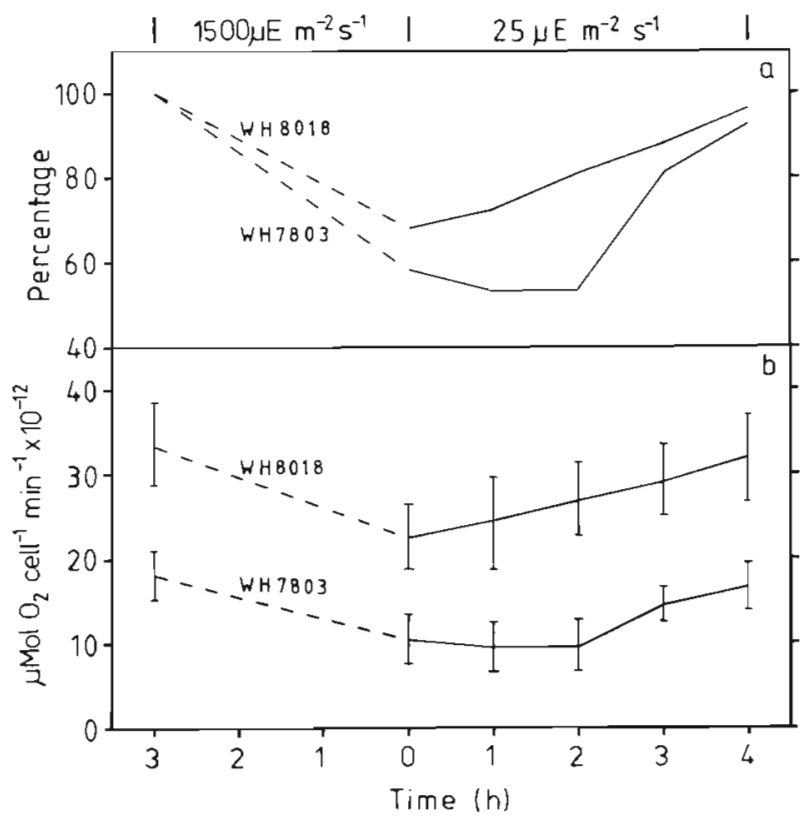

Fig. 1. Synechococcus spp. Clones WH 7803 (DC-2) and WH 8018 (L1604). Time course responses of maximal photosynthetic rates to onset and recovery from photoinhibition. (a) Percent change in photosynthesis; (b) maximal photosynthetic rates. Cells were grown under $25 \mu \mathrm{E} \mathrm{m} \mathrm{m}^{-2} \mathrm{~s}^{-1}$, exposed to photoinhibitory light $\left(1500 \mu \mathrm{E} \mathrm{m}^{-2} \mathrm{~s}^{-1}\right)$ for $3 \mathrm{~h}$ and then returned to prephotoinhibitory light levels. Error bars indicate \pm SD of the mean of 3 replicates

to a $30 \%$ decrease in Clone WH 8018 and a $40 \%$ decrease in WH 7803 (Fig. 1). Upon return to the low light level, $\mathrm{P}_{\max }$ fully recovered within 2 to $3 \mathrm{~h}$ in Clone WH 8018. Clone WH 7803 showed a 2 h lag in recovery of photosynthesis and required 3 to $4 \mathrm{~h}$ to fully recover from the photoinhibitory light exposure (Fig. 1).

Because changes in $\mathrm{P}_{\max }$ are related to PSU features of size and numbers per cell (e.g. Gallagher et al. 1984), we examined the response of the PSU to photoinhibitory light levels. Concomitant with the decreases in $\mathrm{P}_{\max }$ were increases in PSU sizes (total chromophores [Chl a plus total bilin chromophores] per P700) within 3 h (Fig. 2a). Clone WH 8018 showed a $15 \%$ increase in PSU size after $3 \mathrm{~h}$ exposure to photoinhibitory light; findings consistent with high photon flux density effects previously observed (Barlow \& Alberte 1985). Full recovery of PSU sizes to pre-photoinhibitory conditions was achieved in Clone WH 7803 within $4 \mathrm{~h}$, how-

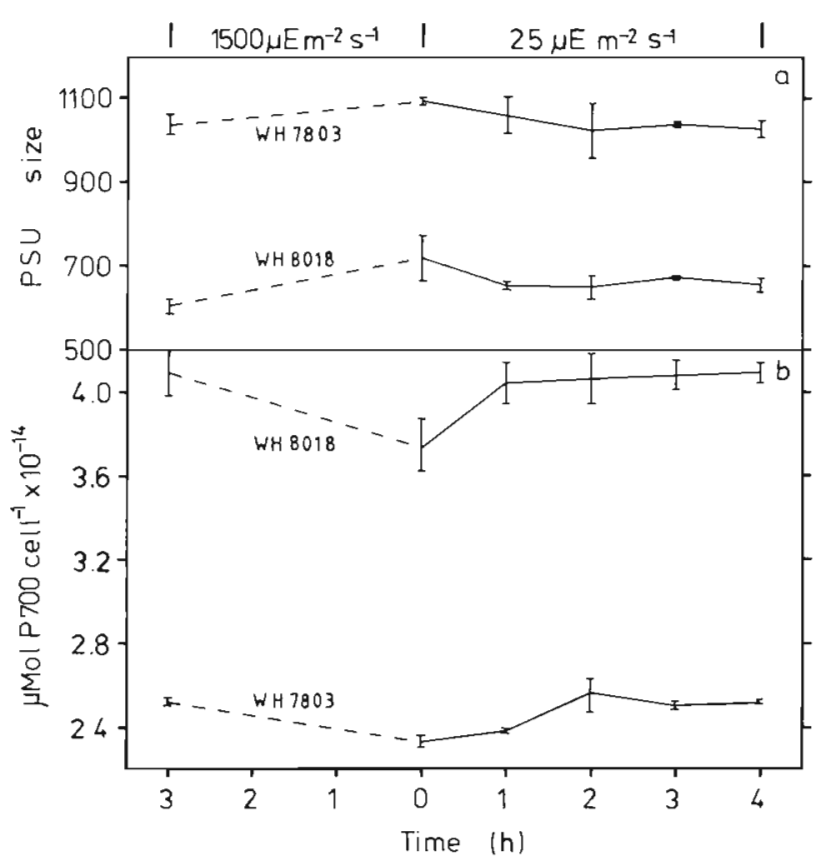

Fig. 2. Synechococcus spp. Clones WH 7803 and WH 8018. Time course responses of photosynthetic unit size (PSU) based on (a) P700, and (b) P700 concentration per cell. Experimental conditions same as in Fig. 1. Error bars indicate \pm SD of the mean of 3 replicates

ever, PSU size in Clone WH 8018 did not fully recover during this period.

Cellular content of P700, or the number of Photosystem I units per cell, declined in both clones in response to photoinhibitory light (Fig. 2b). The numbers of Photosystem I reaction centres declined from 2.5 to $2.3 \mu \mathrm{mol}$ P700 cell $\mathrm{c}^{-1}\left(\times 10^{-14}\right)$ in WH 7803 and 4.1 to

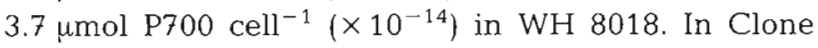
WH 8018, recovery of $\mathrm{P} 700$ photochemical activity was extremely rapid as full recovery was observed within $1 \mathrm{~h}$ after return of the cells to low photon flux densities (Fig. 2b). In Clone WH 7803, P700 recovery lagged behind that of WH 8018, and full recovery was not achieved until $2 \mathrm{~h}$. Interestingly, P700 photochemical activity recovered more rapidly than $\mathrm{P}_{\max }$ in both clones.

In both clones, PE fluorescence emission from whole cells increased as $\mathrm{P}_{\max }$ decreased (Fig. 3a) under photoinhibitory conditions. Clone WH 8018 showed a $45 \%$ increase in PE fluorescence after a $3 \mathrm{~h}$ exposure to 1500 $\mu \mathrm{E} \mathrm{m} \mathrm{m}^{-2} \mathrm{~s}^{-1}$, while Clone WH 7803 only showed a $15 \%$ increase (Fig. 3a). Recovery of pre-photoinhibitory levels of $\mathrm{PE}$ fluorescence was rapid in both clones, though it appears that recovery in -WH 8018 lagged behind that of WH 7803. These increases in PE fluorescence when $\mathrm{P}_{\max }$ was reduced are consistent with previous findings (Barlow \& Alberte 1985), and further verify the relationships between reduced $P_{\max }$. 


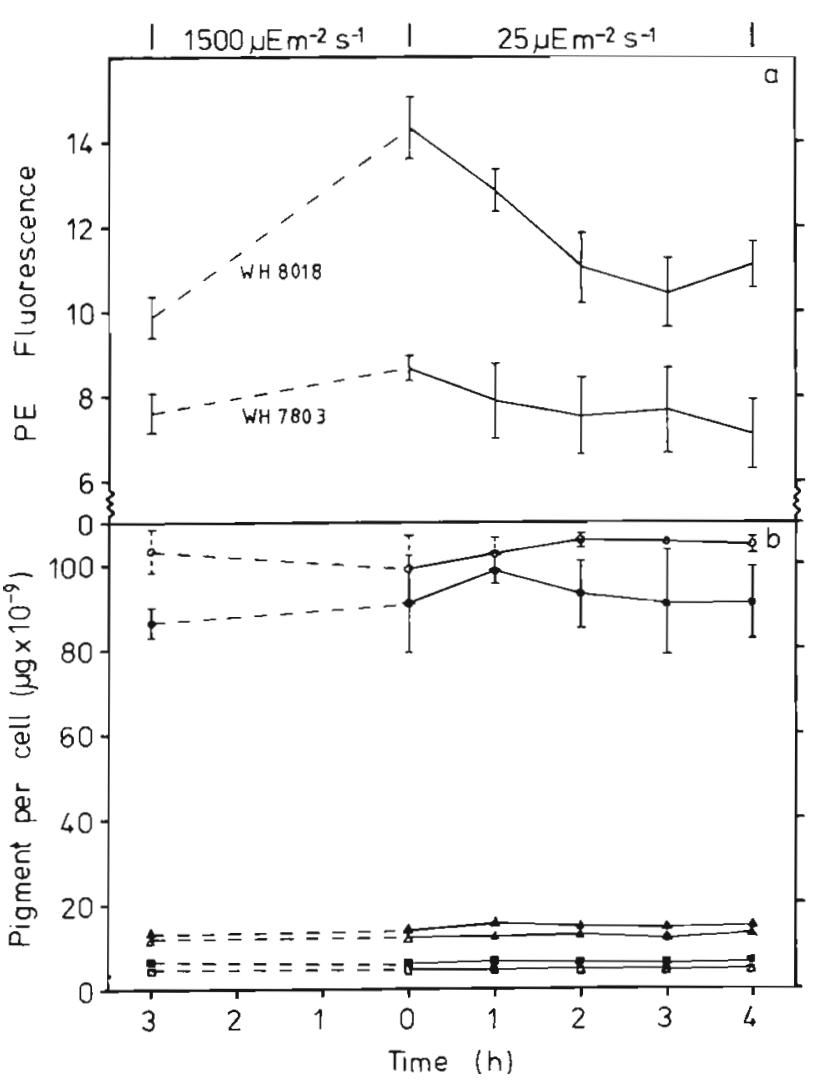

Fig. 3. Synechococcus spp. Clones WH 7803 and WH 8018. Time course responses of (a) phycoerythrin fluorescence relative to chlorophyll a fluorescence emission, and (b) pigment concentration per cell. Experimental conditions same as Fig. 1. The ratio of phycoerythrin fluorescence at 560 (WH 7803 ) or $574 \mathrm{~nm}$ (WH 8018) to chlorophyll a fluorescence at $680 \mathrm{~nm}$ was measured with excitation at $525 \mathrm{~nm}$. In panel (b), open symbols: WH 7803; closed symbols: WH 8018; circles: phycoerythrin; triangles: phycocyanin + allophycocyanin; squares: chlorophyll a. Error bars indicate $\pm \mathrm{SD}$ of the mean of 3 replicates

reduction in $\mathrm{P} 700$ activity and increased PE fluorescence. Reductions in photochemistry and consequently photosynthesis will reduce excitation quenching and result in re-radiation of absorbed photons as fluorescence.

Under photoinhibitory conditions there were no significant changes in Chl $a, P E, P C$ or APC concentrations per cell (Fig. 3b). Based on these data, the increases observed in PSU sizes (Fig. 2a) under photoinhibition were not attributable to addition of lightharvesting pigments to existing PSUs, but due to losses in number of $\mathrm{P700}$ reaction centres. This is substantiated by the observed reductions in amount of P700 per cell (Fig. 2b).

\section{DISCUSSION}

The phenomenon of photoinhibition of photosynthesis has been recognised in natural phytoplankton assemblages (e.g. Goldman et al. 1963, Harris \& Piccinin 1977) and has been credited with reducing primary production in surface water (Belay 1981, Kirk 1983). Indeed, depth profiles of phytoplankton photosynthetic rate per volume can often show a subsurface maximum (Kirk 1983). Harris \& Piccinin (1977) and Belay \& Fogg (1978) found that the onset of photosynthetic photoinhibition was rapid but took up to several hours to reach significant levels. Recovery was slower than inhibition and was dependent upon the photoinhibitory exposure period (Goldman et al. 1963).

In the present investigation we sought to extend the previous findings on photoinhibition in phytoplankton to delineate the related responses in pigment composition, PSU features, fluorescence and primary photochemistry associated with Photosystem I (P700). The studies demonstrated that Synechococcus spp. are rapidly photoinhibited by high photon quantum fluxes, and the reduction in $P_{\max }$ observed corresponds to an increase in whole cell PE fluorescence, an apparent increase in PSU size and to a reduction in Photosystem I reaction centre $(\mathrm{P} 700)$ activity. These findings support the previous suggestion that Photosystem I is the principal site of photoinhibition in these marine cyanobacteria (Barlow \& Alberte 1985). The Photosystem I activity measured here (P700 photo-oxidation in Triton-solubilized membranes) is independent of noncyclic electron flow and Photosystem II activity. Losses in P700 activity have also been observed in response to photoinhibitory light levels in a benthic diatom (Gerber \& Burris 1981) and the green algae Scenedesmus obliquus (Harvey \& Bishop 1978) and Dunaliella tertiolecta (Falkowski 1984).

The photoinhibition of $\mathrm{P}_{\max }$ observed in the 2 Synecchococcus spp. clones examined showed the same time course as loss in P700 activity and increases in PE fluorescence. The recovery time course, however, shows that recovery of P700 activity precedes that of photosynthesis by 1 to $2 \mathrm{~h}$. This indicates that other events, e.g. electron transport, reduction of $Q$, or carbon fixation steps, may also contribute to the photoinhibitory response and have slower recovery times than Photosystem I photochemistry. This suggestion is substantiated by the observation that the recovery kinetics of PE fluorescence parallel those of photosynthesis and not P700 photochemistry.

Though the precise mechanism of photosynthetic photoinhibition is not known, early investigations by Jones \& Kok (1966) demonstrated that the greatest quantum efficiency of photoinhibition was in the ultraviolet (UV) and not in the visible part of the spectrum. Kirk (1983) has suggested that the UV sensitivity may be related to quinones, perhaps those closely associated with the reaction centres (e.g. plastoquinone, iron-quinone electron acceptors). Since 
quinone complexes are among the primary acceptors for Photosystem I in green plants (Malkin 1982), alteration of these complexes leading to inability to conduct oxidation-reduction would prevent the primary donor of Photosystem I, P700, from carrying out photochemistry as well. As such, electron transport would be reduced resulting in increases in fluorescence and reductions in oxygen evolution. These are precisely the symptoms observed when Synechococcus spp. were exposed to high irradiance.

Studies on higher plants have suggested that Photosystem II is the primary site of photoinhibition (Powles \& Critchley 1980), while Samuelsson \& Richardson (1982) suggest this site is responsible for the low photon flux photoinhibitory response in a marine dinoflagellate. Certainly losses in P700 will cause concomitant reductions in Photosystem II activity (Barlow \& Alberte 1985) because non-cyclic electron flow is reduced. It is not clear, however, that losses in Photosystem II activity alone would have as great or as rapid an impact on photosynthesis if cyclic electron transport occurs. Further studies are required to clarify this point and the mechanisms of photoinhibition.

The PE fluorescence relative to $\mathrm{Chl}$ a fluorescence was much greater in Clone WH 8018 than in WH 7803 in response to photoinhibition. This difference can be partly attributed to a greater loss in P700 activity in this clone. In Clone WH 7803 a large (30 to 60\%) proportion of PE is not bound to phycobilisomes (Kursar et al. 1981, Kirchman \& Alberte 1985), and consequently is not coupled energetically to photosynthesis. The level of 'free' PE in Clone WH 8018 is much less (10 to $20 \%$; Barlow \& Alberte 1985, Kirchman \& Alberte 1985). Therefore, under photoinhibitory conditions, increases in PE fluorescence that arise from lower efficiencies of excitation quenching in the reaction centres are masked by the already high 'free' PE fluorescence in Clone WH7803 but are seen in Clone WH 8018 which has a much lower 'free' PE fluorescence. The whole-cell PE fluorescence of Clone WH 7803 is 3-fold greater than that found in Clone WH 8018 (Barlow \& Alberte 1985). Increases in PE fluorescence relative to $\mathrm{Chl}$ a fluorescence may prove to be a reliable assay for photoinhibition in Synechococcus spp. natural assemblages which can be remotely sensed using the dual laser Airborne Optical Lidar system described by Hoge \& Swift (1983).

The comparative aspects of recovery of the 2 clones from photoinhibition may have implications for their success in natural habitats. Clone WH 8018 shows more rapid (1 to 2 h) P700 and $\mathrm{P}_{\max }$ recovery kinetics, and possesses much higher (nearly 2-fold) P700 concentrations per cell than Clone WH 7803. Further, Clone WH 8018 does not show the same degree of photoinhibition of photosynthesis as Clone WH 7803 when P-I relations are compared for cells grown under a range of photon flux densities (Barlow \& Alberte 1985). These features in conjunction with the absorption (Alberte et al. 1984) and fluorescence excitation properties (Alberte \& Barlow 1984) of these clones indicate that Clone WH 8018 is more tolerant of light environments typically found in mid-depth to surface waters than Clone WH 7803 (Alberte et al. 1984). Field observations have shown (Glover et al. 1983) that the DC-2 type clones (WH 7803) predominate in the lower euphotic zone while the 1600-types (WH 8018) have been remotely detected in high abundance in surface waters (Hoge \& Swift 1983).

The kinetic responses of the 2 clones to changing photon flux densities also has significance with regard to their adaptive strategies. Turbulence is an important factor controlling the vertical distribution of phytoplankton (Therriault et al. 1978, Shay \& Gregg 1984) and residence times at any given depth and light environment. Consequently turbulence (Lewis et al. $1984 a, b)$ and the rates of mixing (Marra 1978a, b, Falkowski 1983) have a profound impact on rates of photosynthesis and temporal responses of photoinhibition and photoadaptation. One might argue that a phytoplankton species must not only optimize its light absorption and utilization properties (e.g. PSU sizes and numbers per cell, energy transfer efficiencies) in a given light environment, but, perhaps more importantly, have the capability to change these properties on the same time scale as its light environment changes. Time scales of variability in natural light environments and photoadaptation have been examined in eucaryotic microalgae by others (Marra 1978a, b, Prezelin \& Matlick 1980, Falkowski 1984, Post et al. 1985), but it is clear from this study that light adaptation of PSU features and $\mathrm{P}_{\max }$ in Synechococcus spp. occurs within hours. Therefore, the photoadaptive capabilities previously reported (Barlow \& Alberte 1985) combined with the ability to rapidly recover from photoinhibition certainly contribute to the ubiquity and ecological success of Synechococcus spp. in the world's oceans.

Acknowledgements. We thank Mr A. Hopson for excellent laboratory assistance. We acknowledge the many helpful discussions with Dr David Kirchman during the preparation of the manuscript. This research was supported by a grant (NAGW-460) from the National Aeronautics and Space Administration.

\section{LITERATURE CITED}

Alberte, R. S., Barlow, R. G. (1984). Use of fluorescence excitation spectra to study light adaptation in marine phytoplankton. EOS (Trans. Am. geophys. Un.) 65: 910

Alberte, R. S., Wood, A. M., Kursar, T. A., Guillard, R. R. L. (1984). Novel phycoerythrins in marine Synechococcus 
spp.: characterization, and evolutionary and ecological implications. Pl. Physiol. 75: 732-739

Barlow, R. G., Alberte, R. S. (1985). Photosynthetic characteristics of phycoerythrin-containing marine Synechococcus spp. I. Responses to growth photon flux density, Mar. Biol. 86: 63-74

Belay, A. (1981). An experimental investigation of inhibition of phytoplankton photosynthesis at lake surfaces. New Phytol. 89: 61-74

Belay, A., Fogg, G. E. (1978). Photoinhibition of photosynthesis in Asterionella formosa (Bacillariophyceae). J. Phycol. 14: 341-347

Falkowski, P. G. (1983). Light-shade adaptation and vertical mixing of marine phytoplankton: a comparative field study. J. mar. Rès. 41: 215

Falkowski, P. G. (1984). Light-shade adaptation to irradiance in Dunaliella tertiolecta. Photosynthetica 18: 62-68

Gallagher, J. C., Wood, A. M., Alberte, R. S. (1984). Ecotypic differentiation in the marine diatom Skeletonema costatum: influence of light intensity on the photosynthetic apparatus. Mar. Biol. 82: 121-134

Gerber, D. W., Burris, J. E. (1981). Photoinhibition and P700 in the marine diatom Amphora sp. Pl. Physiol. 68: 699-702

Glover, H. E., Keller, M. D. (1984). The effects of light quality and intensity on marine ultraplankton clones from the Sargasso Sea. EOS (Trans. Am. geophys. Un.) 65: 910

Glover, H. E., Smith, A. E., Murphy, L. S. (1983). Variability in composition and photosynthetic activity of photoautotrophic picoplankton communities. EOS (Trans. Am. geophys. Un.) 64: 1984

Goldman, C. R., Mason, D. T., Wood, B. J. B. (1963). Light injury and inhibition in Antarctic freshwater plankton Limnol. Oceanogr. 8: 313-322

Guillard, R. R. L., Ryther, J. H. (1962). Studies on marine planktonic diatoms. I. Cyclotella nana Hustedt and Detonula confervacea (Cleve) Gran. Can. J. Microbiol. 8 229-239

Harris, G. P., Piccinin, B. B. (1977). Photosynthesis by natural phytoplankton populations. Arch. Hydrobiol. 80: 405-457

Harvey, G. W., Bishop, N. I. (1978). Photolability of photosynthesis in two separate mutants of Scenedesmus obliquus Pl. Physiol. 62: 330-336

Hoge, F. E., Swift, R. N. (1983). Airboume dual laser excitation and mapping of phytoplankton in a Gulf Stream Warm Core Ring. Appl. Optics 22: 2272-2281

Jeffrey, S. W., Humphrey, G. F. (1975). New spectrophotometric equations for determining chlorophylls $a, b, c_{1}$ and $c_{2}$ in higher plants, algae and natural phytoplankton. Biochem Physiol. Pflanz. 167: 191-194

Johnson, P. W., Sieburth, P. W. (1979). Chroococcoid cyanobacteria in the sea: ubiquitous and diverse phototrophic biomass. Limnol. Oceanogr. 24: 928-935

Jones, L. W., Kok, B. (1966). Photoinhibition of chloroplasts reactions. Pl. Physiol. 41: 1037-1043

Kirchman, A. L., Alberte, R. S. (1985). Phycoerythrin as a nitrogen storage pool in marine Synechococcus. EOS (Trans. Am. geophys. Un.) 66: 1302

Kirk, J. T O. (1983). Light and photosynthesis in aquatic ecosystems. Cambridge Univ. Press, Cambridge

Kursar, T. A., Alberte, R. S. (1983). Photosynthetic unit organization in a red alga: relationships between light-harvesting pigments and reaction centres. Pl. Physiol. 72: 409-414

Kursar, T. A., Swift, H., Alberte, R. S. (1981). Morphology of a novel cyanobacterium and characterization of light-harvesting complexes from it: implications for phycobiliprotein evolution. Proc. natn. Acad. Sci. U.S.A. 78: 6888-6892

Lewis, M. R., Horne, E. P. W., Cullen, J. J., Oakey, N. S., Platt, T. (1984a). Turbulent motions may control phytoplankton photosynthesis in the upper ocean. Nature, Lond. 311: $49-50$

Lewis, M. R., Cullen, J. J., Platt, T. (1984b). Relationships between vertical mixing and photoadaptation of phytoplankton: similarity criteria. Mar. Ecol. Prog. Ser. 15 $141-149$

Li, W. K. W., Subba Rao, D. V., Harrison, W. G., Smith, J. C. Cullen, J. J., Irwin, B., Platt, T. (1983). Autotrophic picoplankton in the tropical ocean. Science 219: 292-295

Malkin, R. (1982). Photosystem I. A. Rev. Pl. Physiol. 33 $455-479$

Marra, J. (1978a). Effect of short-term variations in light intensity on photosynthesis of a marine phytoplankter: a laboratory simulation study. Mar. Biol. 46: 191-202

Marra, J. (1978b). Phytoplankton photosynthetic response to vertical movement in the mixed layer. Mar. Biol. 46: 203-208

Morris, I., Glover, H. E. (1981). Physiology of photosynthesis by marine coccoid cyanobacteria - some ecological implications. Limnol. Oceanogr. 26: 957-961

Perry, M. J., Talbot, M. C., Alberte, R. S. (1981). Photoadaptation in marine phytoplankton: response of the photosynthetic unit. Mar. Biol. 62: 91-101

Platt, T., Subba Rao, D. V., Irwin, B. (1983). Photosynthesis of picoplankton in the oligotrophic ocean. Nature, Lond. 301 702-704

Post, A. F., Dubinsky, Z., Wyman, K., Falkowski, P. G. (1985). Physiological responses of a marine planktonic diatom to transitions in growth irradiance. Mar. Ecol. Prog. Ser. 25: $141-149$

Powles, S. B., Critchley, C. (1980). The effect of light intensity during growth on photoinhibition of intact attached bean leaflets. Pl. Physiol. 65: 1181-1187

Prezelin, B. B., Matlick, H. A. (1980). Time-course of photoadaptation in the photosynthesis-irradiance relationship of a dinoflagellate exhibiting photosynthetic periodicity. Mar. Biol. 58: 85-96

Richardson, K., Beardall, J., Raven, J. A. (1983). Adaptation of unicellular algae to irradiance: an analysis of strategies. New Phytol. 93: 157-191

Samuelsson, G., Richardson, K. (1982). Photoinhibition at low quantum flux densities in a marine dinoflagellate. Mar. Biol. 70: 21-26

Shay, T J., Gregg, M. C. (1984). Turbulence in an oceanic convective mixed layer. Nature, Lond. 310: 282-285

Therriault, J. C., Lawrence, D. J., Platt, T. (1978). Spatial variability of phytoplankton turnover in relation to physical processes in a coastal environment. Limnol. Oceanogr 23: 900-911

Waterbury, J. B., Watson, S. W., Guillard, R. R. L., Brand, L. E. (1979). Widespread occurrence of a unicellular, marine, planktonic, cyanobacterium. Nature, Lond. 277: 293-294

Waterbury, J. B., Watson, S. W., Valois, F. (1983). The role of marine unicellular planktonic cyanobacteria: an overview: EOS (Trans. Am. geophys. Un.) 64: 1084

Yentsch, C. S. (1984). The relative contribution of light absorption and photosynthetic capacity by procaryotes - an indirect approach. EOS (Trans. Am. geophys. Un.) 65: 910 